\title{
Geographical innovations in the flora of the Mangystau region
}

\author{
Akzhunis A. Imanbayeva ${ }^{1 *}$, Margarita Yu. Ishmuratova ${ }^{1}$, and Gulnara G. Gassanova ${ }^{1}$ \\ ${ }^{1}$ Mangyshlak Experimental Botanical Garden of Science Committee of Ministry of Education and \\ Science of Republic of Kazakhstan, $10^{\text {th }}$ micro district, 100000, Aktau, Kazakhstan
}

\begin{abstract}
This article gives the new 7 species to the flora of vascular plants of Mangystau region (Artemisia sieversiana Willd., Ribes aureum Pursh, Tulipa gerneriana L. (T. schrenkii Regn. M. Roem., Tulipa patens Agardh ex Schult. \& Schult.fil, Malus siversii (Ledeb.) M. Roem., Urtica dioica $\mathrm{L}$. and Lonicera tatarica $\mathrm{L}$.). The plants are discovered during expeditionary research 2013-2018 on the territory of the Western Karatau Range, the South Aktau Range, the North Ustyurt Plateau and the Tyubkaragan Peninsula. The short information on floristic innovations is given. The updated composition of the flora of vascular plants of the Mangystau region was 684 species.
\end{abstract}

\section{Introduction}

The number of regions had previously been well studied in Kazakhstan, as evidenced by the publication of the detailed 9-volume determinant "Flora of Kazakhstan" [1]. Districts of the Western Kazakhstan, including Mangystau region, still remain poorly studied in floristic terms, research on which has intensified in the last two decades [2-6]. This is due to inaccessibility, vast sparsely populated areas and the lack of a developed road transport network.

Mangystau vegetation belongs to the desert type, formed under the influence of factors which are characteristic of the arid regions: hot and dry climate; high solar insolation; sharp daily and seasonal variations in air temperature and humidity; poverty, salinity, salty and poor soils.

The generalization and analysis of floristic collections let us to publish the first summaries of vascular plants of the Mangystau region [5-7], which included 675 species from 300 genera and 69 families, however, the list of rare and disappeared plants with 40 species was clarified and expanded.

In 2009, 2 two geographical new species for the Mangystau flora were collected and described: Corydalis schanginii (Pall.) B. Fedtsch. and Gagea ova Stopt. [8]. Both species were collected on the Western chink of the Ustyurt plateau.

Over the past 5 years (2013-2018), during botanical expeditions, additional information was stolen and collected new data about the location of 7 species for the Mangystau flora: Arte-

* Corresponding author: imangarden@mail.ru 
misia sieversiana Willd., Ribes aureum Pursh, Tulipa gerneriana L. (T. schrenkii Regn. M. Roem., Tulipa patens Agardh ex Schult. \& Schult.fil, Malus siversii (Ledeb.) M. Roem., Urtica dioica L. and Lonicera tatarica L.

\section{Materials and methods}

Field investigations are carried out by route reconnaissance. During the expeditionary work, significant herbarium material was collected (stored in the herbarium fund of the Mangyshlak Experimental Botanical Garden), the processing of which made it possible to identify 7 geographical innovations that were not previously cited.

Families and genera are given according to the publication of M.S. Baitenov [9], the Latin name of plants according to the summary of S.K. Czerepanov [10], the description of species and distribution is given according to the Flora of Kazakhstan [1], the Determinant of vascular plants of Kazakhstan [11, 12], the Determinant of plants of the Central Asia [13, 14].

\section{Results and discassion}

The geographical new for the flora of Mangystau species:

Family Asteraceae Dumort.

Artemisia sieversiana Willd. Biennial plant. It is described along the dirt road in the northeastern part of the Western Karatau ridge (12.07.2013). Coordinates of location: N 44.21214, E 52.05118, 26 m above sea level. Weed species. It blooms VII, fruits VIII.

Family Caprifoliaceae Juss.

Lonicera tatarica L. Bush. It lives on the slopes and bottom of the gorges of the Northern Ustyurt, forming continuous plots of communities (19.07.2013; 07.05.2017). It booms $\mathrm{V}$, fruits VI-VIII. Coordinates of location: gorge in $22 \mathrm{~km}$ from the descent of Manata-Ata N 44.08194, E 53.16196, $80.4 \mathrm{~m}$ above sea level.

Family Grossulariaceae DC.

Ribes aureum Pursh. Bush. The well-developed individuals are identified in the Karaturan gorge of the South Aktau ridge (04.06.2013). They are located along the bottom of the gorge under Morus alba trees. Coordinates of location: N 44,12625, E 51,32059, $148 \mathrm{~m}$ above sea level. It annually blooms in V and fruits in VII.

Family Liliaceae Juss.

Tulipa gerneriana L. (T. schrenkii Regel). Perennial plant. It grows on slopes of hills, on flat sites, along streams and temporary water currents in the territory of the reserve area of Kolenkeli (Ustyurt plateau) (01.05.2017; 02.05.2017; 05.05.2018). Several places of growth are revealed. Coordinates of locations: 1) slopes of hills - N 46.17269, E 55.33271, $68.4 \mathrm{~m}$ above sea level; 2) the plain along the dry stream - N 46.16423, E 55.30156, $98.7 \mathrm{~m}$ above sea level; 3) Mount Kolenkele - N 46.18202, E 55.28015, 196 m above sea level; 4) the Karazhanyrak rill - N 46.15002, E 55.25110, $95 \mathrm{~m}$ above sea level; 5) the Mount Toksanbay - N 46.02411, E 56.13196, $64.6 \mathrm{~m}$ above sea level; 6) vicinities of the Shogyrla Shomishta rill - N 45.38496, E 55.40593, 129 m above sea level. It blooms IV-V, fruits VVI.

Tulipa patens Agardh ex Schult. \& Schult.fil. Perennial plant. It grows in the steppes, on the crushed and rocky slopes of the hills of the Kolenkeli reserve in the vicinity of Mount Toksanbay (Ustyurt plateau). Coordinates of location: N 46.02411, E 56.13196, $64.6 \mathrm{~m}$ above sea level. It blooms IV-V, fruits VI.

Family Rosaceae Juss. 
Malus siversii (Ledeb.) M. Roem. Tree. Single specimens are described in the Akmysh gorge of the Western Karatau ridge (13.07.2015). Coordinates of location: N 44.13345, E $51.59028,266 \mathrm{~m}$ above sea level. Plants bloom in IV-V, fruits in VII-VIII.

Family Urticaceae Juss.

Urtica dioica L. Perennial plant. It is noted in Tamshaly's gorge of the peninsula Tyubkaragan (24.07.2013); spots of thickets grow along a stream on a gorge bottom. Coordinates of location: N 44.35229, E 50.35572, $133 \mathrm{~m}$ above sea level. It blooms VI-VII, fruits VIII.

\section{Discussion}

Artemisia sieversiana is widespread in the territory of Kazakhstan; the general distribution covers practically all territory of Eurasia. The species is characteristic of steppe and mountain territories, is often dated for settlements, agricultural grounds, abandoned arable lands. Earlier for Mangystau Region the finds of this species were absent. It is possible to assume that it was brought from the territory of the Atyrau region. The present location is an extreme western point of an area of Artemisia sieversiana in Kazakhstan.

Lonicera tatarica in Kazakhstan grows in the following floristic regions: Spurs of the common Syrt, Tobolo-Ishim, Irtysh, Kokshetau, Caspian, Aktobe, Turgai, Western and Eastern lowlands, Ulytau, Karkaraly, Zaysan, Moyynkumsky, Balkhash-Alakol, in the foothills of Altai, Tarbagatai, Soongari, Transily, Ketmen, Terskey and the Kyrgyz AlaToo. The found habitats are unique for Lonicera tatarica, since this shrub prefers mesophyte conditions. In the gorges of the Northern Ustyurt, this species develops territories with rill, streams and close occurrence of fresh water. The discovered population occupies the south-western part of the area of this species.

Ribes aureum is not found in the natural flora of Kazakhstan, is a feral species. In the gorge Karaturan probably settled as an arrogant from cultivated specimens.

Tulipa gerneriana grows in a steppe, semi-desert and desert zone of Kazakhstan. For the desert of Mangyshlak this species was not described. Finding of this species is an extreme western point of an area. Earlier the area was limited to Spurs of Common Syrt Plateau, valleys of rivers Tobol, Ishim, Emba, a steppe zone of the Aktyubinsk region, the Mountains Mugodzhary, Ulytau and the Central Kazakhstan lowlands.

Tulipa patens in Kazakhstan lives in the Tobolo-Ishimsky floristic area, in the valley of the Irtysh River, on the Kokshetau uplands, the Turgay Plateau, the Central Kazakhstan lowlands, in Mountains Karkaraly, on the Zaysan hollow, Aral region, desert Kyzylkumy, in a foothill zone of Altai. Detection of this population on Mangyshlak is the most western point of an area of Tulipa patens in Kazakhstan.

Malus siversii in the republic covers the mountainous territories of the South and Southeast Kazakhstan, therefore, the discovered habitat of the species is very far from the main populations.

Urtica dioica usually grows along ravines, under the canopy and on the edges of forests, as weed in housing, usually prefers mesophytic conditions. It is found in almost all regions of Kazakhstan, although it was not given for the Mangystau region. The discovered population is located on the southwestern extreme border of the range of this species in Kazakhstan.

\section{Conclusions}

Taking into account the above species, the flora of vascular plants of the Mangystau region includes 684 species. Herbarium samples of species which are new to the flora of the Man- 
gystau region are stored in the funds of the Mangyshlak Experimental Botanical Garden (Aktau).

The work was carried out with the financial support of scientific-technical program of the Committee of Science of the Ministry of Education and Science of the Republic of Kazakhstan (BR05236506).

\section{References}

1. Flora of Kazakhstan. Alma-Ata: Nauka, 1-9 (1956-1966)

2. Plant catalogue of the West Kazakhstan region (Uralsk, Western-Kazakhstan State University, 2011)

3. S.A. Aitpeisova, Conspectus of the flora of the Aktyubinsk floristic district (Aktobe, Aktobe State University named after M. Zhubanov, 2012)

4. T.E. Darbayeva, Conspectus of the flora of Cretaceous uplands of the North-West Kazakhstan (Uralsk, 2002)

5. I.N. Safronova, Deserts of Mangyshlak (essay of vegetation) (Saint-Petersburg, Botanical Institute, 1996)

6. G.M. Kudabayeva, Bulletin of Kazakh National University, series ecology. 2, 25-28 (2010)

7. N.K. Aralbay, G.M. Kudabayeva, A.A. Imanbayeva, et al. The state inventory of plants of Mangystau region. The list of higher vascular plants (Aktau, 2006)

8. A.A. Imanbayeva, I.N. Safronova, Bulletin of National Academy of Science, series biol. \& medic. 2, 115-116 (2010)

9. M.S. Baitenov, Flora of Kazakhstan. Vol. 1: Illustrated determinant of families and genera (Almaty, Gylym, 1999)

10. S.K. Czerepanov, Vascular plants of Russia and adjacent state (the former USSR). (Cambridge, University Press, 1995).

11. Illustrated determinant of plants of Kazakhstan (Alma-Ata6, Nauka, 1969)

12. Illustrated determinant of plants of Kazakhstan (Alma-Ata, Nauka, 1972)

13. The determinant of plants of the Central Asia. Tashkent: FAN, 2, 37 (1974)

14. The determinant of plants of the Central Asia. Tashkent: FAN, 4, 20 (1974) 